ARTICLE

DOI: $10.1038 / s 41467-018-03286-w$

\title{
The effects of currents and potentials on the selectivities of copper toward carbon dioxide electroreduction
}

\author{
Dan Ren (1) ${ }^{1}$, Jinhuan Fong ${ }^{1} \&$ Boon Siang Yeo (1) ${ }^{1,2}$
}

Copper electrodes have been shown to be selective toward the electroreduction of carbon dioxide to ethylene, carbon monoxide, or formate. However, the underlying causes of their activities, which have been attributed to a rise in local pH near the surface of the electrode, presence of atomic-scale defects, and/or residual oxygen atoms in the catalysts, etc., have not been generally agreed on. Here, we perform a study of carbon dioxide reduction on four copper catalysts from -0.45 to $-1.30 \mathrm{~V}$ vs. reversible hydrogen electrode. The selectivities exhibited by 20 previously reported copper catalysts are also analyzed. We demonstrate that the selectivity of carbon dioxide reduction is greatly affected by the applied potentials and currents, regardless of the starting condition of copper catalysts. This study shows that optimization of the current densities at the appropriate potential windows is critical for designing highly selective copper catalysts.

\footnotetext{
${ }^{1}$ Department of Chemistry, Faculty of Science, National University of Singapore, 3 Science Drive 3, Singapore 117543, Singapore. ${ }^{2}$ Solar Energy Research Institute of Singapore (SERIS), National University of Singapore, 7 Engineering Drive 1, Singapore 117574, Singapore. Correspondence and requests for materials should be addressed to B.S.Y. (email: chmyeos@nus.edu.sg)
} 
T he reduction of carbon dioxide $\left(\mathrm{CO}_{2}\right)$ to fuels and chemical feedstocks using renewable electricity has the potential of becoming a key component in the development of a sustainable carbon cycle ${ }^{1,2}$. This process requires selective, efficient, and stable electrocatalysts before it can be implemented in the industrial scale. Among the metal electrocatalysts studied, copper is the only metal that can reduce $\mathrm{CO}_{2}$ to significant amounts of hydrocarbons and oxygenates ${ }^{3,4}$. Of these products, methods to selectively form formate $\left(\mathrm{HCOO}^{-}\right)^{5}$, carbon monoxide $(\mathrm{CO})^{6}$, methane $\left(\mathrm{CH}_{4}\right)^{7}$, ethylene $\left(\mathrm{C}_{2} \mathrm{H}_{4}\right)^{8-10}$ and ethanol $\left(\mathrm{C}_{2} \mathrm{H}_{5} \mathrm{OH}\right)^{11}$ have been extensively pursued.

To understand how these products are formed on copper, Peterson and Nørskov modeled the reduction of $\mathrm{CO}_{2}$ on $\mathrm{Cu}(211)$ surface (a stepped surface) using density functional theory (DFT) ${ }^{12}$. As the applied potential became more negative, $\mathrm{CO}_{2}$ was first reduced to $\mathrm{HCOO}^{-}$and $\mathrm{CO}$, from $-0.41 \mathrm{~V}$ vs. RHE (reversible hydrogen electrode) onward. $\mathrm{C}_{2} \mathrm{H}_{4}$ and $\mathrm{CH}_{4}$ were the next major products and evolved at potentials negative to $-0.71 \mathrm{~V}$ vs. RHE. These theoretical predictions are consistent with the findings reported earlier by Hori et al. on a polycrystalline $\mathrm{Cu}$ surface, where $\mathrm{HCOO}^{-}$and $\mathrm{CO}$ were produced first, followed by $\mathrm{C}_{2} \mathrm{H}_{4}$ and $\mathrm{CH}_{4}{ }^{13}$. Interestingly, when $\mathrm{Cu}$ single-crystal surfaces were studied using chronopotentiometry at $-5 \mathrm{~mA} \mathrm{~cm}^{-2}$ in $0.1 \mathrm{M}$ $\mathrm{KHCO}_{3}$ electrolyte, the selectivity between $\mathrm{C}_{2} \mathrm{H}_{4}$ and $\mathrm{CH}_{4}$ changed. $\mathrm{Cu}(100)$ and $\mathrm{Cu}(111)$ were, respectively, found selective for $\mathrm{C}_{2} \mathrm{H}_{4}$ and $\mathrm{CH}_{4}$ formation. Further optimization of $\mathrm{C}_{2} \mathrm{H}_{4}$ production could be achieved by using stepped- $\mathrm{Cu}(100)$ surfaces $^{14}$. For example, the faradaic efficiency (FE) of $\mathrm{C}_{2} \mathrm{H}_{4}$ reached $50 \%$, while $\mathrm{CH}_{4}$ was suppressed to $5 \%$ on a $\mathrm{Cu}(\mathrm{S})-[4(100) \times(111)]$ electrode polarized at $-5 \mathrm{~mA} \mathrm{~cm}^{-2}(-0.94 \mathrm{~V}$ vs. RHE). Oddly and still without an explanation, the selectivity of neither $\mathrm{C}_{2} \mathrm{H}_{4}$ nor $\mathrm{CH}_{4}$ seemed to improve significantly on stepped- $\mathrm{Cu}(111)$ surfaces.

Besides the $\mathrm{Cu}(100)$ single-crystal series, some oxide-derived $\mathrm{Cu}$ catalysts have also shown a propensity for $\mathrm{C}_{2} \mathrm{H}_{4}$ and $\mathrm{C}_{2} \mathrm{H}_{5} \mathrm{OH}$ production $^{8-10,15,16}$. For example, we have found that at $-0.99 \mathrm{~V}$ vs. RHE, $\mathrm{Cu}$ films reduced from $\mu \mathrm{m}$-thick $\mathrm{Cu}_{2} \mathrm{O}$ could catalyze the reduction of $\mathrm{CO}_{2}$ in $0.1 \mathrm{M} \mathrm{KHCO}_{3}$ electrolyte to $\mathrm{C}_{2} \mathrm{H}_{4}$ with FEs $=34-39 \%$, while the FEs of $\mathrm{CH}_{4}$ were minimized to $<1 \%$. Interestingly, thick oxide-derived $\mathrm{Cu}$ films, which do not appear to have very different morphological and chemical differences as the aforementioned $\mathrm{C}_{2}$-selective catalysts, have also been independently reported to be selective toward the formation of $\mathrm{CO}$ and $\mathrm{HCOO}^{-5,6}$. The selective reduction of $\mathrm{CO}_{2}$ to $\mathrm{CH}_{4}$ on $\mathrm{Cu}$ surfaces has been relatively less studied. Recently, Manthiram et al. reported that $7 \mathrm{~nm}$-sized $\mathrm{Cu}$ nanoparticles dispersed on a glassy carbon electrode could catalyze the formation of $\mathrm{CH}_{4}$ with an average $\mathrm{FE}$ of $80 \%$ in $0.1 \mathrm{M} \mathrm{NaHCO}_{3}$ at $-1.25 \mathrm{~V}$ vs. $\mathrm{RHE}^{7}$.

Based on characterizations of the catalysts presented in the above reports, the underlying causes for the selective reduction of $\mathrm{CO}_{2}$ to various products on $\mathrm{Cu}$ catalysts have been attributed to factors such as morphology ${ }^{9}$, particle sizes ${ }^{17,18}$, crystallite sizes and facets (for example, $\mathrm{Cu}(100))^{18}$, grain boundaries ${ }^{19}$, strains ${ }^{20}$, presence of residual oxygen $\left(\mathrm{or} \mathrm{Cu}^{+}\right)^{10,21}$, and rise in local $\mathrm{pH}$ at the surface of the electrode ${ }^{8}$. However, the effect of applied potential on the selectivity of these catalysts, as shown earlier by Peterson and Nørskov has been largely neglected or sidestepped in these important works ${ }^{12}$.

Here, we address this inadequacy by studying a series of $\mathrm{Cu}$ catalysts (metallic film and oxide-derived films) with different roughness factors for the electroreduction of $\mathrm{CO}_{2}$. We find that the selectivities of $\mathrm{CO}_{2}$ reduction toward $\mathrm{HCOO}^{-} / \mathrm{CO}, \mathrm{C}_{2} \mathrm{H}_{4}$, and $\mathrm{CH}_{4}$ are observed to occur at different potential windows, as long as the mass transport limitation of $\mathrm{CO}_{2}$ is not reached. Furthermore, this finding can be used to explain the selectivities exhibited by a range of $\mathrm{Cu}$ single-crystal surfaces and nanostructures. We also discuss the role of oxide in oxide-derived $\mathrm{Cu}$ catalysts for the enhanced formation of $\mathrm{CO}, \mathrm{HCOO}^{-}$, and $\mathrm{C}_{2} \mathrm{H}_{4}$.

\section{Results}

Characterization of the catalysts. The copper catalysts were prepared via electrodeposition ${ }^{22}$. By tuning the $\mathrm{pH}$ of the electrolyte and the deposition time, four different films were deposited (Supplementary Figure 1). These catalysts were characterized by scanning electron microscopy (SEM), selected area electron diffraction (SAED, with transmission electron microscopy, TEM), and Raman spectroscopy (Fig. 1). As shown by their SAED patterns, 10 min depositions using $\mathrm{pH}=10.5$ electrolyte led to the formation of metallic $\mathrm{Cu}$ films $(\mathrm{Cu}-10)$, while the other three catalysts deposited using $\mathrm{pH}=13.2$ electrolyte for $1 \mathrm{~min}, 10 \mathrm{~min}$, and 60 min were all $\mathrm{CuO}$ (termed as $\mathrm{CuO}-1, \mathrm{CuO}-10$, and $\mathrm{CuO}-$ 60 , respectively). The morphologies of the four films before and after $\mathrm{CO}_{2}$ reduction were revealed by SEM. The surface of $\mathrm{Cu}-10$ consisted of $\mu \mathrm{m}$-sized particles before reduction (Fig. 1a). The surfaces of $\mathrm{CuO}-1, \mathrm{CuO}-10$, and $\mathrm{CuO}-60$ were covered with $10-100 \mathrm{~nm}$ particles, though the nanoparticles of CuO-60 agglomerated as $\mu \mathrm{m}$-sized particles (Fig. $1 \mathrm{~b}-\mathrm{d}$ ). After reduction, there was no significant morphology change for all four catalysts (Fig. 1e-h). The roughness factors (RFs) of post-reduced $\mathrm{Cu}-10$, $\mathrm{CuO}-1, \mathrm{CuO}-1$, and $\mathrm{CuO}-60$ were estimated by the double layer capacitance method to be 1.4, 5, 48, and 186, respectively (Supplementary Figure 2 and Supplementary Table 1).

The Raman spectra of the three $\mathrm{CuO}$ films exhibited peaks at $293,308,338$, and $610 \mathrm{~cm}^{-1}$, which could be assigned to signals from $\mathrm{CuO}$ (Fig. 1i) ${ }^{22,23}$. According to the Pourbaix diagram of the $\mathrm{Cu}-\mathrm{H}_{2} \mathrm{O}$ system, the three $\mathrm{CuO}$ samples would be reduced to the metallic state under $\mathrm{CO}_{2}$ reduction potentials, i.e., potentials more negative than $-0.50 \mathrm{~V}$ vs. RHE (all potentials cited in this work are referenced to the RHE) ${ }^{24}$. This was further verified by operando Raman spectroscopy of the catalysts (representative data for CuO-60 in Fig. 1j). Upon application of an electrochemical potential of $-0.50 \mathrm{~V}$ vs. RHE, the 293,338 , and $610 \mathrm{~cm}$ ${ }^{-1}$ peaks of $\mathrm{CuO}$ disappeared within $140 \mathrm{~s}$. From $140 \mathrm{~s}$ onward, three bands at 280,360, and $2090 \mathrm{~cm}^{-1}$ appeared. These can be, respectively, assigned to the restricted rotation of bound $\mathrm{CO}$, the $\mathrm{Cu}-\mathrm{CO}$ stretching and $\mathrm{C} \equiv \mathrm{O}$ stretching modes ${ }^{25-27}$. These bands were also observed on $\mathrm{CuO}-60$ at more negative potentials from -0.60 to $-0.80 \mathrm{~V}$ (Supplementary Figure 3), where hydrocarbons such as $\mathrm{C}_{2} \mathrm{H}_{4}$ were formed with appreciable quantities $\left(\mathrm{FE}_{\text {ethylene }}\right.$ $=3-19 \%)$. This observation is consistent with previous reports that indicates $\mathrm{CO}$ is a key intermediate formed during the reduction of $\mathrm{CO}_{2}$ to hydrocarbons on $\mathrm{Cu}$ catalysts ${ }^{13,28}$. The appearance of $\mathrm{Cu}-\mathrm{CO}$ signals only after the $\mathrm{CuO}$ signals have disappeared indicates that the active sites for $\mathrm{CO}_{2}$ reduction are likely to be metallic $\mathrm{Cu}$. The reduction of oxide is also indicated by the chronoamperogram, which showed a reduction peak in the first $100 \mathrm{~s}$ (Fig. 1j).

The effects of limiting currents and applied potentials on $\mathrm{CO}_{2}$ reduction activity. The electrochemistry of our four catalysts toward $\mathrm{CO}_{2}$ reduction was assessed using $60 \mathrm{~min}$ chronoamperometry in aqueous $0.1 \mathrm{M} \mathrm{KHCO}_{3}$ electrolyte. A threeelectrode setup ${ }^{29}$ was used and the products were quantified using gas chromatography and high performance liquid chromatography ${ }^{2}$.

The total current density and $\mathrm{CO}_{2}$ reduction current density are presented in Fig. 2a, b. In general, the total current densities exhibited by the catalysts correlated positively with the latters' roughness factors and with the overpotentials applied. However, the $\mathrm{CO}_{2}$ reduction current densities on the four catalysts exhibited parabolic-like trends against the applied potentials, 


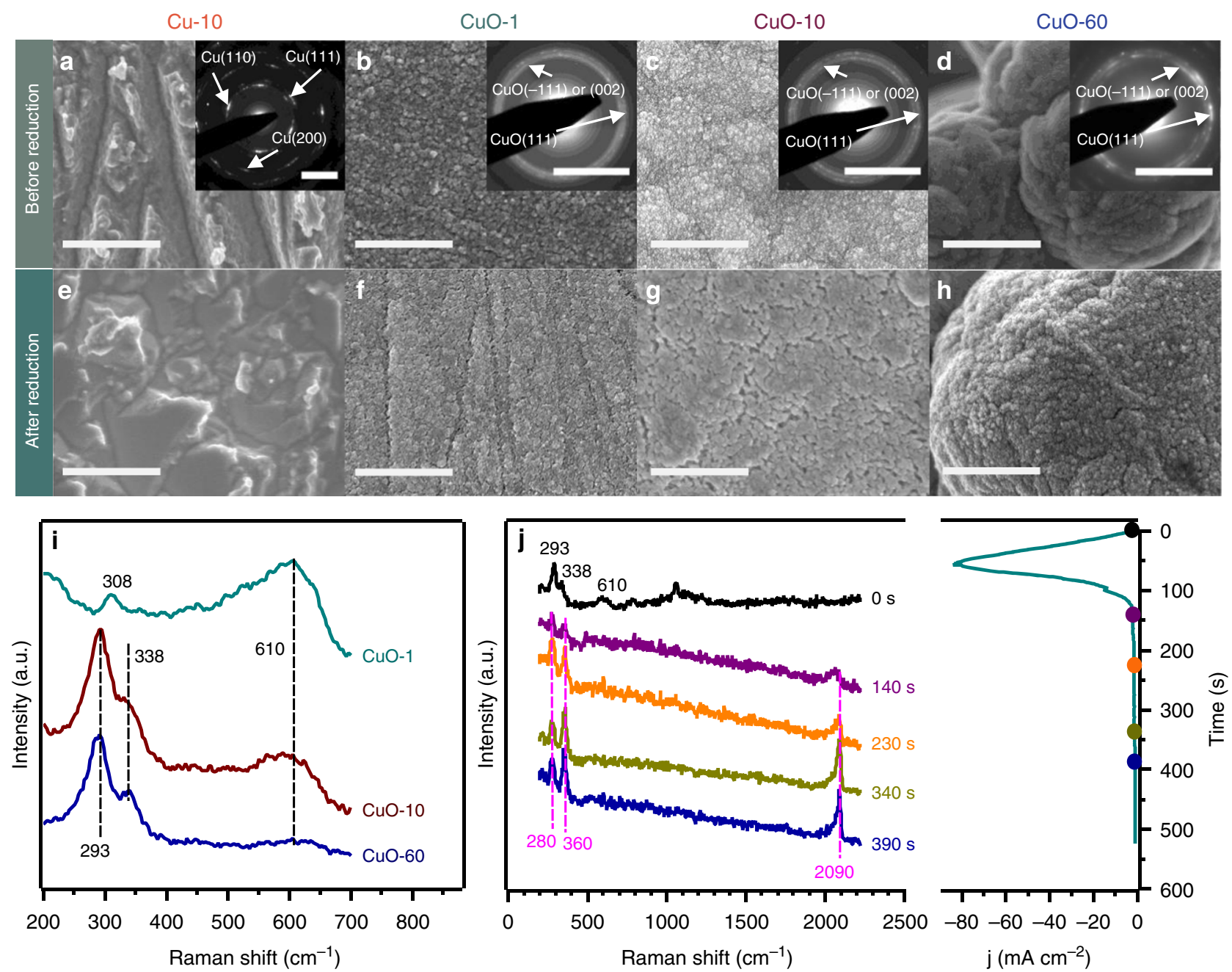

Fig. 1 Material characterization of four catalysts. SEM images and SAED patterns (inserts) of (a) Cu-10, (b) CuO-1, (c) CuO-10, and (d) CuO-60 catalysts before reduction; SEM images of (e) Cu-10, (f) CuO-1, (g) CuO-10, and (h) CuO-60 catalysts after reduction; (i) Raman spectra of Cu oxide surfaces collected ex situ and (j) operando Raman spectroscopy with the simultaneously obtained chronoamperogram of $\mathrm{CuO}^{-60}$ during $\mathrm{CO}_{2}$ reduction in $0.1 \mathrm{M}$ $\mathrm{KHCO}_{3}$ at $-0.5 \mathrm{~V}$ vs. RHE. Scale bars: $1 \mu \mathrm{m}$ for SEM (a-g) and $5 \mathrm{~nm}^{-1}$ for SAED (inserts of a-d)

with maxima of about $-20 \mathrm{~mA} \mathrm{~cm} \mathrm{~cm}^{-2}$. These maxima corresponded to total current densities of about $-40 \mathrm{~mA} \mathrm{~cm}^{-2}$. Beyond the limiting total current density, the $\mathrm{CO}_{2}$ reduction current densities decreased and the selectivity toward $\mathrm{H}_{2}$ production increased. The limiting $\mathrm{CO}_{2}$ current can be attributed to the mass transport limitation of $\mathrm{CO}_{2}$ to the electrode, as $\mathrm{CO}_{2}$ has a poor solubility in aqueous electrolytes $\left(\sim 34 \mathrm{mM}\right.$ at $\left.25^{\circ} \mathrm{C}\right)$. Additionally, as the total current increased with applied overpotentials, there will also be a buildup of $\mathrm{OH}^{-}$near the electrode surface, i.e., an increase in local $\mathrm{pH}$. This will cause a decrease in local concentration of $\mathrm{CO}_{2}$ near the electrode surface, resulting in the fall in $\mathrm{CO}_{2}$ reduction currents ${ }^{30,31}$. These findings are supported by numerical simulations of the concentrations of $\mathrm{CO}_{2}$ and local $\mathrm{pH}$ values at the $\mathrm{Cu}$ surface (using $\mathrm{Cu}-10$ as the model; Supplementary Figure 4). As the simulated current increased to $-90 \mathrm{~mA} \mathrm{~cm}{ }^{-2}$, the local $\mathrm{pH}$ increased from a bulk value of 6.8 to 11.5 , while the local $\mathrm{CO}_{2}$ concentration fell from $34 \mathrm{mM}$ to $6.5 \mathrm{mM}^{32}$.

The FEs of major $\mathrm{CO}_{2}$ reduction products are presented in Fig. 2c-e (Supplementary Tables 2-5). We found that a slightly roughened metallic $\mathrm{Cu}$ surface $(\mathrm{Cu}-10, \mathrm{RF}=1.4)$ exhibited excellent $\mathrm{CH}_{4}$ selectivity at $-1.2 \mathrm{~V}$ with $\mathrm{FE}_{\text {methane }}$ of $62 \%$. The oxide-derived $\mathrm{Cu}$ surfaces $(\mathrm{CuO}-1, \mathrm{RF}=5 ; \mathrm{CuO}-10, \mathrm{RF}=48$, and
CuO-60, $\mathrm{RF}=186)$ were generally more selective for $\mathrm{C}_{2} \mathrm{H}_{4}$ and $\mathrm{C}_{2} \mathrm{H}_{5} \mathrm{OH}$ (up to total $\mathrm{FE}$ of $48 \%$ ) $^{9,19}$. Interestingly, CuO-1 also exhibited a good selectivity toward $\mathrm{CH}_{4}$ at $-1.15 \mathrm{~V}$ with a $\mathrm{FE}$ of $40 \%$. This observation appears unusual as oxide-derived $\mathrm{Cu}$ films are hitherto not known to be selective toward the formation of $\mathrm{CH}_{4}{ }^{5,9}$. We also note that the roughest sample, $\mathrm{CuO}-60$, gave relatively high selectivities for $\mathrm{CO}$ and $\mathrm{HCOO}^{-}$at low overpotentials $\left(\mathrm{FE}_{\mathrm{CO}}=46 \%\right.$ at $-0.50 \mathrm{~V}$ and $\mathrm{FE}_{\text {formate }}=35 \%$ at $-0.60 \mathrm{~V})$.

Another observation is that the catalytic selectivity toward the formation of different products was only observed in specific potential ranges. At potentials more positive than $-0.7 \mathrm{~V}, \mathrm{CO}$ and $\mathrm{HCOO}^{-}$(maximum total $\mathrm{FE}=75 \%$ at $-0.55 \mathrm{~V}$ ) were significantly formed. From -0.8 to $-1.1 \mathrm{~V}, \mathrm{C}_{2} \mathrm{H}_{4}$ and $\mathrm{C}_{2} \mathrm{H}_{5} \mathrm{OH}$ were produced in great quantities by all the $\mathrm{CuO}$ catalysts. As the overpotential increased further (more negative than $-1.1 \mathrm{~V}$ ), $\mathrm{CH}_{4}$ was selectively produced (high $\mathrm{CH}_{4}$ selectivity on $\mathrm{Cu}-10$ at -1.15 $\mathrm{V}$ and $\mathrm{CuO}-1$ at $-1.2 \mathrm{~V}$ ). Only small amounts of $\mathrm{CH}_{4}$ were produced using $\mathrm{CuO}-10$ and $\mathrm{CuO}-60$. This is likely because their total current density exceeded the limiting current density of -40 $\mathrm{mA} \mathrm{cm}{ }^{-2}$ after the potential reached more negative to $-1.1 \mathrm{~V}$, which caused significant decrease of the $\mathrm{CO}_{2}$ concentration near the electrode. 

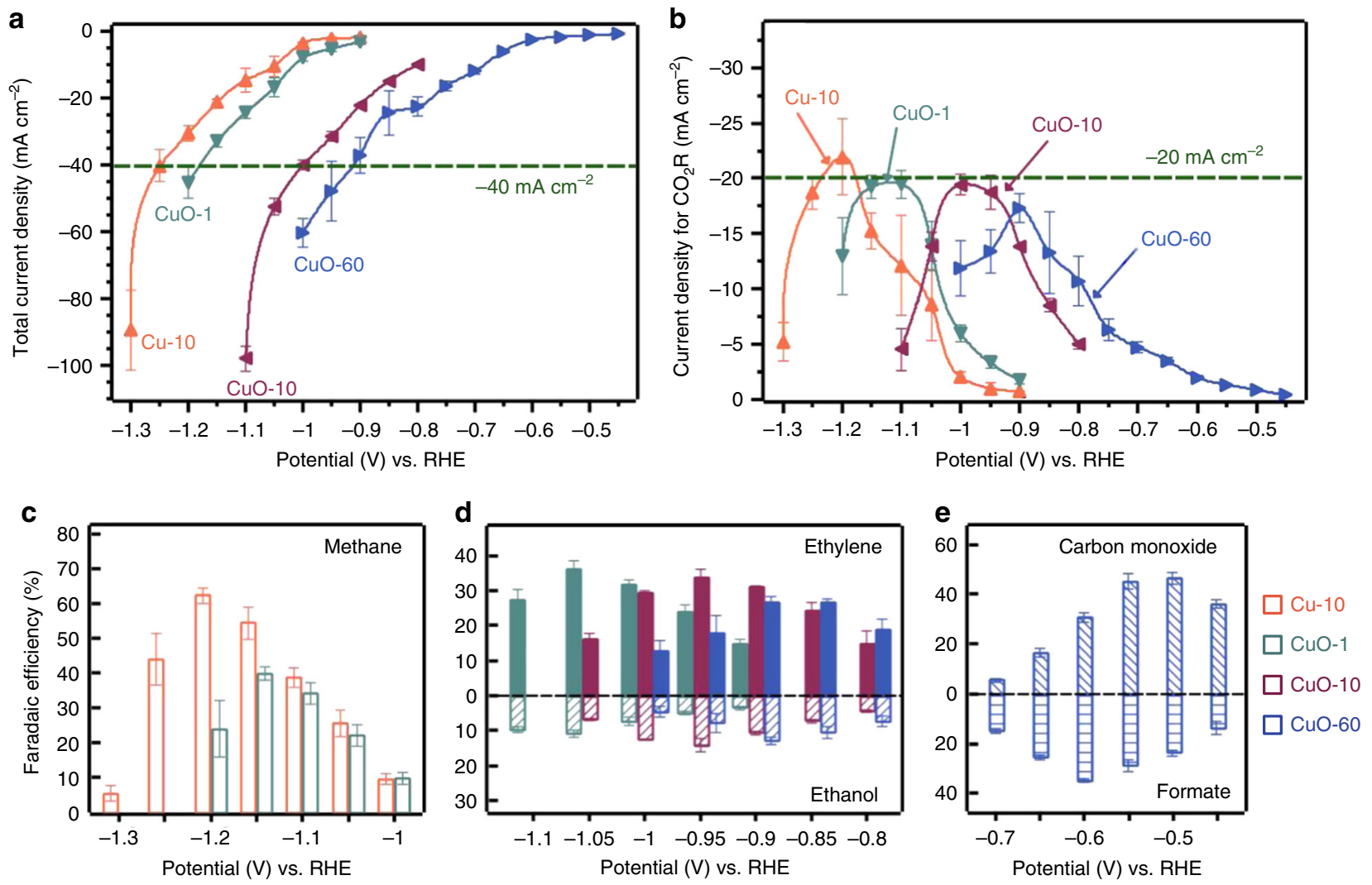

Fig. 2 Electrocatalytic performance of four catalysts toward carbon dioxide electroreduction. a Total geometric current density and $\mathbf{b}$ current density for $\mathrm{CO}_{2}$ reduction $\left(\mathrm{CO}_{2} \mathrm{R}\right)$ on four catalysts at different potentials; $\mathbf{c}$ faradaic efficiency of methane on $\mathrm{Cu}-10$ and $\mathrm{CuO}-1$ catalysts at different potentials; $\mathbf{d}$ faradaic efficiency of ethylene and ethanol on $\mathrm{CuO}-1, \mathrm{CuO}-10$, and $\mathrm{CuO}-60$ catalysts at different potentials; e faradaic efficiency of carbon monoxide and formate on CuO-60 catalyst at different potentials. Error bars in a-e represent the standard deviations of three independent measurements

Proposed mechanism for the formation of major $C_{1}$ and $C_{2}$ products. Considering the electrocatalytic properties of different $\mathrm{Cu}$ catalysts and the DFT calculations reported in the literature ${ }^{12,33-36}$, we propose a mechanism for the formation of major $\mathrm{C}_{1}$ and $\mathrm{C}_{2}$ products (Fig. 3). After one proton and one electron transfer, $\mathrm{CO}_{2}$ could be reduced to either ${ }^{\star} \mathrm{OCHO}$ or ${ }^{\star} \mathrm{COOH}$ intermediate. Further reduction of ${ }^{\star} \mathrm{OCHO}$ and ${ }^{\star} \mathrm{COOH}$ lead to the respective formation of $\mathrm{HCOO}^{-}$and ${ }^{\star} \mathrm{CO}$. The presence of ${ }^{\star} \mathrm{CO}$ as an intermediate species of $\mathrm{CO}_{2}$ reduction is demonstrated by our operando Raman spectroscopy results in Fig. $1 \mathrm{j}$ and Supplementary Figure 3. In agreement with previous studies on a range of $\mathrm{Cu}$ catalysts, we found that the potential-dependent profile of $\mathrm{HCOO}^{- \text {'s }}$ faradaic efficiency does not exactly follow that of $\mathrm{CO}$ on CuO-60 (Fig. 2e $)^{4-6,9}$. This indicates that $\mathrm{CO}$ and $\mathrm{HCOO}^{-}$may not have been formed through the same ${ }^{*} \mathrm{COOH}$ intermediate ${ }^{34,36}$. This finding is consistent with recent DFT calculations, which shows that the activities of a range of metallic catalysts toward $\mathrm{HCOO}^{-}$formation correlate better with their binding energies to ${ }^{\star} \mathrm{OCHO}$ intermediates ${ }^{36}$. ${ }^{\star} \mathrm{CO}$ could be further reduced to $\mathrm{CH}_{4}$, or undergo $\mathrm{C}-\mathrm{C}$ coupling with another ${ }^{\star} \mathrm{CO}$ to form $\mathrm{C}_{2} \mathrm{H}_{4}$ and $\mathrm{C}_{2} \mathrm{H}_{5} \mathrm{OH}$. It is notable that to-date copper is the only metal electrode capable of facilitating these value-added reactions at reasonable rates as ${ }^{\star} \mathrm{CO}$ is optimally bonded to it $(\mathrm{Cu}$ resides near the top of the volcano plot) ${ }^{37}$. We have also recently proposed a $\mathrm{CO}$-insertion mechanism for the formation of $\mathrm{C}_{2} \mathrm{H}_{5} \mathrm{OH}$ in a $\mathrm{CO}$ rich environment ${ }^{11}$. The different energy barriers in the multiple pathways to form $\mathrm{CO}, \mathrm{HCOO}^{-}, \mathrm{C}_{2} \mathrm{H}_{4}$, $\mathrm{C}_{2} \mathrm{H}_{5} \mathrm{OH}$, and $\mathrm{CH}_{4}$ could be the reason why these products were observed at different potential windows (Fig. $2 \mathrm{c}-\mathrm{e})^{38}$.

\section{Discussion}

On the basis of the preceding results, we propose here that the effects of tuning the morphology of a $\mathrm{Cu}$ catalyst may not solely lie in creating catalytically active sites (as commonly believed) $9,39-41$, but also affects its roughness so that the material operates with a suitable current density at a particular potential. Here, we discuss this proposition in conjunction with previous works (Fig. 4, Supplementary Tables 6 and 7). In Hori's classic work, a constant current of $-5 \mathrm{~mA} \mathrm{~cm}{ }^{-2}$ was applied during $\mathrm{CO}_{2}$ reduction on all the $\mathrm{Cu}$ single crystals ${ }^{14,42}$. Under these conditions, $\mathrm{Cu}(100)$ and $\mathrm{Cu}(111)$ were, respectively, more selective for $\mathrm{C}_{2} \mathrm{H}_{4}$ and $\mathrm{CH}_{4}$ formation. Introducing (110) atomic steps to $\mathrm{Cu}$ (100) terraces to create high index surfaces was shown to further enhance $\mathrm{C}_{2} \mathrm{H}_{4}$ selectivity. These studies suggest that surface crystallography is paramount in the control of product selectivity. However, two recent $\mathrm{CO}_{2}$ reduction studies performed at various potentials $(-0.30--1.25 \mathrm{~V}$ by our group and $-0.89--1.15 \mathrm{~V}$ by Hahn et al.) revealed that $\mathrm{Cu}(100)$ could also reduce $\mathrm{CO}_{2}$ to $\mathrm{CH}_{4}$ with $\mathrm{FE}$ of $30-44 \%$ at about $-1.1 \mathrm{~V}$ (Fig. $4 \mathrm{a})^{43,44}$. It is remarkable that the enhanced selectivities for $\mathrm{CH}_{4}, \mathrm{C}_{2} \mathrm{H}_{4}$, and $\mathrm{HCOO}^{-}$formation (the formation of CO is generally $<15 \%$ in these studies) on all the surfaces studied are most pronounced in distinct potential ranges. At potentials negative or equal to $-1.1 \mathrm{~V}, \mathrm{CH}_{4}$ selectivity was enhanced and the faradaic efficiency of $\mathrm{C}_{2} \mathrm{H}_{4}$ was low on $\mathrm{Cu}(111)$ and $\mathrm{Cu}(100)$. At potentials more positive than $-1.0 \mathrm{~V}, \mathrm{C}_{2} \mathrm{H}_{4}$ selectivity was observed and the $\mathrm{FE}$ of $\mathrm{CH}_{4}$ was suppressed to $<10 \%$, including on $\mathrm{Cu}(111)$. High faradaic efficiencies (FE) of $\mathrm{HCOO}^{-}$were observed at potentials more positive to $-0.9 \mathrm{~V}$ on single crystals, especially on $\mathrm{Cu}(110)$. These evidences indicate that the applied potential is a crucial factor for 

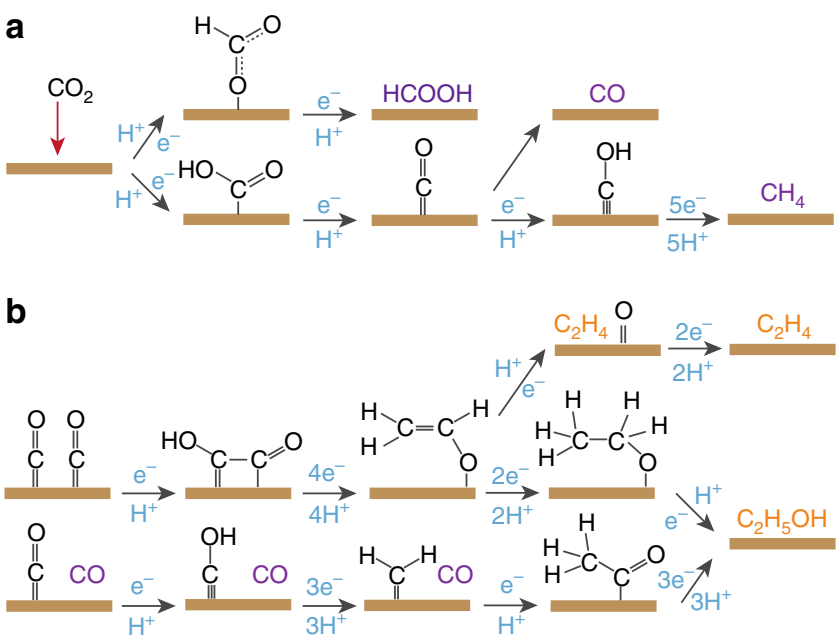

Fig. 3 Proposed mechanism for carbon dioxide electroreduction. a The pathway to $C_{1}$ products (formate, carbon monoxide, and methane) and $\mathbf{b}$ the pathway to $C_{2}$ products (ethylene and ethanol). Water molecules are not drawn and the formation of $\mathrm{C}_{2}$ products is drawn from carbon monoxide. Purple color indicates a free $C_{1}$ molecule and orange color indicates a free $\mathrm{C}_{2}$ molecule

the selectivities of different $\mathrm{Cu}$ single crystals. The corollary is that the frequently generalized statement 'enhanced $\mathrm{CH}_{4}$ selectivity using $\mathrm{Cu}(111)$ ' or 'enhanced $\mathrm{C}_{2} \mathrm{H}_{4}$ selectivity using $\mathrm{Cu}(100)$ ' is only true under specific conditions ${ }^{14,41,42}$.

Besides $\mathrm{Cu}$ single crystals, we found that the selectivities of 20 other copper catalysts including metallic nanoparticles, oxidederived nanoparticles, nanorods, etc. were also greatly affected by the applied potentials (Fig. 4b). To achieve a high selectivity of $\mathrm{CH}_{4}$ on catalysts, such as isolated $\mathrm{Cu}$ nanoparticles ${ }^{7}$, polycrystalline $\mathrm{Cu}^{4,13}$, as well as $\mathrm{Cu}-10$ in this study, the applied potential was always more negative than $-1.1 \mathrm{~V}$ (solid circles). Note that these catalysts have relatively smooth surfaces and as such, do not exhibit current density that exceeds $-40 \mathrm{~mA} \mathrm{~cm}^{-2}$ (the limiting current density) at negative potentials $\sim-1.2 \mathrm{~V}$. For catalysts that favor $\mathrm{C}_{2} \mathrm{H}_{4}$ formation such as $\mathrm{Cu}_{2} \mathrm{O}$ films ${ }^{8-10}, \mathrm{Cu}$ nanoparticles ${ }^{45}, \mathrm{Cu}$ nanocubes ${ }^{31,40,46,47}, \mathrm{Cu}$ nanocrystals ${ }^{45}$, and $\mathrm{CuO}$ films in this study, the optimum potential range was from -0.9 to $-1.1 \mathrm{~V}$ (solid squares). $\mathrm{CO}$ and $\mathrm{HCOO}^{-}$selectivity were usually observed on rough and thick oxide-derived $\mathrm{Cu}$ films at potentials positive to $-0.7 \mathrm{~V}^{5,6,8,10,45,48}$.

Hence, the top three regions in Fig. $4 \mathrm{~b}$ (from left to right) indicates the most suitable potential ranges for the selective formation of $\mathrm{CH}_{4}, \mathrm{C}_{2} \mathrm{H}_{4}$, and $\mathrm{CO} / \mathrm{HCOO}^{-}$, which are, respectively, about $<-1.1 \mathrm{~V},-0.9 \mathrm{~V}$ to $-1.1 \mathrm{~V}$, and $>-0.9 \mathrm{~V}$. It is notable that outside their suitable potential windows, these products are usually produced with $\mathrm{FE}<15 \%$ (hollow shapes in the bottom three regions of Fig. $4 \mathrm{~b}$ ). For example, the FE of $\mathrm{C}_{2} \mathrm{H}_{4}$ using 'ethylene-selective' catalysts were $<11 \%$ at potentials negative to $-1.1 \mathrm{~V}$ or positive to $-0.8 \mathrm{~V}$ (hollow squares). We note here that the selectivities of some catalysts could not be clearly defined at the potentials interfacing two potential windows, such as at $-0.90 \mathrm{~V}$. For instance, apart from catalyzing the reduction of $\mathrm{CO}_{2}$ to $\mathrm{C}_{2} \mathrm{H}_{4}$ at $-0.90 \mathrm{~V}(\mathrm{FE}=15 \%), \mathrm{CuO}-1$ could also catalyze the formation of $\mathrm{HCOO}^{-}$with an appreciable faradaic efficiency of $\sim 20 \%$. However, its selectivity toward $\mathrm{HCOO}^{-}$is lower compared with that of the thicker films $\left(\mathrm{HCOO}^{-}\right.$forms at a $\mathrm{FE}$ of $35 \%$ on $\mathrm{CuO}-60$ at $-0.60 \mathrm{~V})$.

The potential windows highlighted in Fig. 4 are applicable to reports where the surfaces of the catalysts were particulate or planar, the electrolysis cell was similar to the design of Kuhl et $\mathrm{al}^{4}$ and the electrolyte was aqueous $0.1 \mathrm{M} \mathrm{KHCO}_{3}$ or other similar electrolytes (such as $0.1 \mathrm{M} \mathrm{NaHCO}_{3}$ ). Studies using significantly different cell designs ${ }^{49}$, gas diffusion electrodes ${ }^{16}$, nanoneedles, or nanofoams $\mathrm{s}^{50}$ may exhibit different potential ranges for a specific product since these systems may have higher limiting current densities. The use of $\mathrm{KOH}$ or $\mathrm{KCl}$ electrolytes ${ }^{16,51}$ may introduce other effects such as high local $\mathrm{pH}$, and thus, do not fit properly in the above-defined regions.

The aforementioned potential windows (Fig. 4) also show that the DFT predictions made by Peterson and Nørskov on how potentials affect product selectivity is not only applicable to $\mathrm{Cu}$ (211) surfaces $^{12}$, but can also be applied to a variety of $\mathrm{Cu}$ catalysts such as $\mathrm{Cu}$ single crystals, oxide-derived $\mathrm{Cu}$ and $\mathrm{Cu}$ nanostructures, as long as mass transport limitation of $\mathrm{CO}_{2}$ has not been reached.

It is interesting that $\mathrm{CuO}-1$, an oxide, exhibited a surprisingly high faradaic efficiency of $\mathrm{CH}_{4}$ (Fig. 2c). In fact, from -0.95 to $-1.15 \mathrm{~V}$, the $\mathrm{FE}$ of $\mathrm{CH}_{4}$ on $\mathrm{CuO}-1$ (3-40\%) and $\mathrm{Cu}-10(2-54 \%)$ are comparable. This observation is remarkable because oxidized $\mathrm{Cu}$ catalysts are known for their propensity to reduce $\mathrm{CO}_{2}$ to $\mathrm{C}_{2}$ products, rather than to $\mathrm{CH}_{4}{ }^{8-10}$. Hence, this result indicates that the presence of oxide is not the most crucial factor in determining selectivity between $\mathrm{CH}_{4}$ and $\mathrm{C}_{2} \mathrm{H}_{4}$. We further note that an electropolished $\mathrm{Cu}$ surface would be oxidized once exposed to air (which is almost inevitable during sample transfer) and yet, this catalyst is known to produce high $\mathrm{FE}$ of $\mathrm{CH}_{4}$ at negative potentials (Fig. 4b) ${ }^{4}$.

An insight could also be gained from the selectivities exhibited by oxide-derived $\mathrm{Cu}$ catalysts reported by many groups, including Kanan, Baltrusaitis, and ours $5,6,8,9,31,48$. These films have been reported selective toward the reduction of $\mathrm{CO}_{2}$ to either $\mathrm{HCOO}^{-}$ or $\mathrm{C}_{2}-\mathrm{C}_{3}$ products. This behavior is intriguing if we consider that the chemical identities and morphologies (in the nanometer scale) of these films do not appear very different ${ }^{8}$. For example, using a thick layer of $\mathrm{Cu}$ oxide (prepared by annealing a $\mathrm{Cu}$ foil at $500{ }^{\circ} \mathrm{C}$ for 12 hours), Kanan et al. reported FEs of $47 \%$ for $\mathrm{CO}$ and $39 \%$ for $\mathrm{HCOO}^{-}$at -0.35 and $-0.55 \mathrm{~V}$, respectively. $\mathrm{C}_{2} \mathrm{H}_{4}$ was formed at a maximum $\mathrm{FE}$ of only $\sim 5 \%$ at $-0.95 \mathrm{~V}^{5}$. The production of $\mathrm{C}_{2} \mathrm{H}_{4}$ is, thus, notably lower than that on a polycrystalline $\mathrm{Cu}$ surface $(\mathrm{FE}=23 \%$ at $-0.97 \mathrm{~V})$ and our oxidederived $\mathrm{Cu}$ films $(34-39 \% \text { at }-0.99 \mathrm{~V})^{9,13}$. The fact that Kanan's $\mathrm{Cu}$ sample exhibited rather low selectivities toward $\mathrm{C}_{2} \mathrm{H}_{4}$ seem to contradict with observations made by Baltrusaitis et al. and our group. We propose here a simple explanation for this observation: apart from the slightly different electrolytes used, we highlight that the high total current density (about $-25 \mathrm{~mA} \mathrm{~cm}^{-2}$ ) exhibited by Kanan's annealed $\mathrm{Cu}$ at $-0.95 \mathrm{~V}$ will result in a lower local concentration of $\mathrm{CO}_{2}$ near the electrode surface. This will cause an overall lowering of the $\mathrm{FE}$ for $\mathrm{CO}_{2}$ reduction and consequently, a decreased formation of $\mathrm{C}_{2} \mathrm{H}_{4}$ at $-0.95 \mathrm{~V}$. Our observation indicates that thick oxide films will not be suitable for $\mathrm{C}_{2} \mathrm{H}_{4} / \mathrm{C}_{2} \mathrm{H}_{5} \mathrm{OH}$ formation, once their roughness factors exceed the optimum ${ }^{9}$.

Schouten and Koper have measured the onset potentials required for the formation of $\mathrm{CH}_{4}$ and $\mathrm{C}_{2} \mathrm{H}_{4}$ during $\mathrm{CO}$ reduction on $\mathrm{Cu}(100)$ and $\mathrm{Cu}(111)$ electrodes ${ }^{52,53}$. It was shown that $\mathrm{C}_{2} \mathrm{H}_{4}$ could be formed at $\sim 400 \mathrm{mV}$ lower overpotential compared to $\mathrm{CH}_{4}$ on $\mathrm{Cu}(100)$ in $\mathrm{pH}=7$ electrolyte. $\mathrm{C}_{2} \mathrm{H}_{4}$ was further proposed to be formed via a $\mathrm{CO}$ dimerization pathway on $\mathrm{Cu}$ (100). Although this study had revealed the potential-dependence of $\mathrm{C}_{2} \mathrm{H}_{4}$ formation on $\mathrm{Cu}(100)$, we draw here a more general trend of how the electrochemical potential affects the selectivity of $\mathrm{CO}_{2}$ reduction for a wide range of $\mathrm{Cu}$ surface structures. The effect of limiting current density on selectivities is also addressed here. 
a

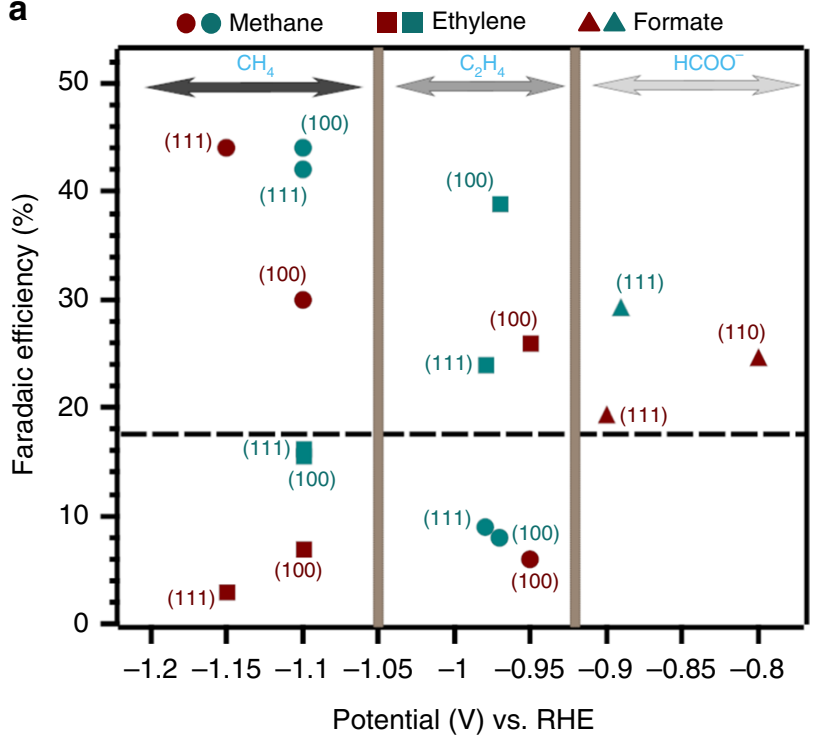

b

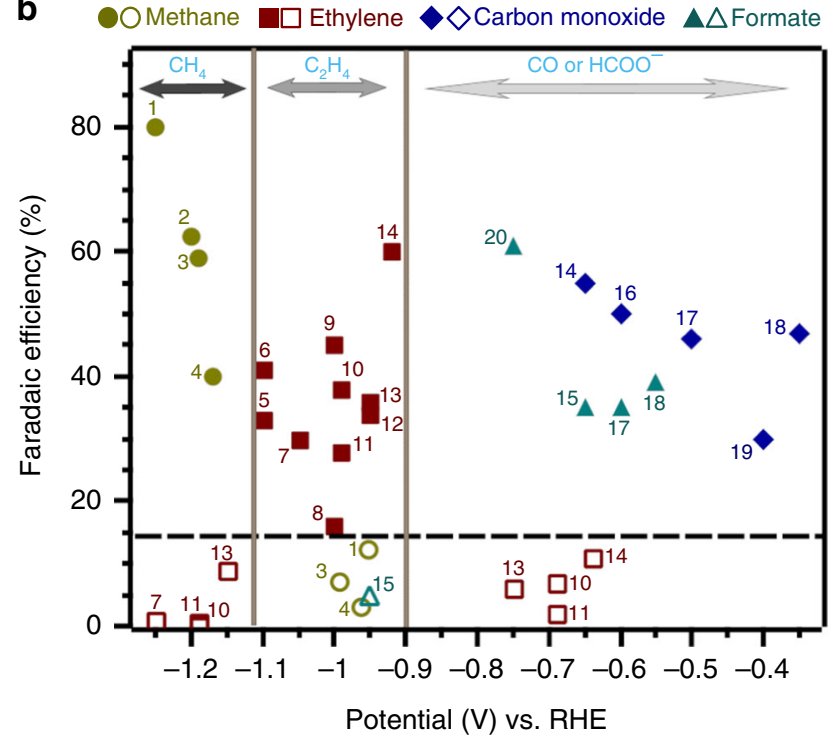

Fig. 4 Potential windows for the selective formation of different products. a Faradaic efficiency of ethylene, methane, and formate on different copper single crystals at different potentials from ref. ${ }^{43}$ (wine) and ref. ${ }^{44}$ (cyan). b The selectivities of 20 different Cu catalysts reported by 11 different research groups at different applied potentials. (1) isolated particles-ref. ${ }^{7}$; (2) $\mathrm{Cu}-10$ in this work; (3) polycrystalline-ref. ${ }^{9}$; (4) polycrystalline-ref. ${ }^{4}$; (5) $\mathrm{Cu}_{2} \mathrm{O}$ (3 $\mathrm{C} \mathrm{cm}$ ${ }^{-2}$ )-ref. ${ }^{8}$; (6) $44 \mathrm{~nm}$ cubes-ref. ${ }^{47}$; (7) nanoparticles-ref. ${ }^{45}$; (8) $\mathrm{KF}$ roughened $\mathrm{Cu}$-ref. ${ }^{46}$; (9) electrochemically cycled $\mathrm{Cu}-$ ref. ${ }^{31}$; (10) $\mathrm{Cu}_{2} \mathrm{O}(1.7$ $\mu \mathrm{m})$-ref. ${ }^{9}$; (11) mesocrystals-ref. ${ }^{40} ;(12) \mathrm{CuO}-10$ in this work; (13) nanocrystals (Cu-NC10)-ref. ${ }^{45} ;(14) \mathrm{Cu}_{2} \mathrm{O}\left(\mathrm{O}_{2}\right.$ plasma 20 min-ref. ${ }^{10} ;(15)$ nanocrystals (Cu-NC2O)-ref. ${ }^{45}$; (16) $\mathrm{CuO}$ nanowire-ref. ${ }^{6}$; (17) CuO-60 in this work; (18) $\mathrm{Cu}_{2} \mathrm{O}$ (annealing) $-\mathrm{ref}^{5}{ }^{5} ;(19) \mathrm{Cu}_{2} \mathrm{O}\left(11 \mathrm{C} \mathrm{cm}^{-2}\right)-r e f .{ }^{8}$; $(20)$ $\mathrm{CuO}$ nanoparticles-ref. ${ }^{48}$

Finally, our work highlights how we could design $\mathrm{Cu}$ catalysts with various selectivities-it is critical to control the surface roughness such that the limiting current density lies in the suitable potential window for $\mathrm{CH}_{4}, \mathrm{C}_{2} \mathrm{H}_{4}$, or $\mathrm{CO} / \mathrm{HCOO}^{-}$. In order to achieve a high selectivity of $\mathrm{CH}_{4}$ formation, the catalyst should be relatively smooth so that the limiting current density is not exceeded at the very negative applied potentials needed (i.e., more negative than $-1.2 \mathrm{~V}$ ). With a roughness factor of $1.4, \mathrm{Cu}-10$ catalyst exhibits both high faradaic efficiency (62\%) and high partial current density $\left(-18 \mathrm{~mA} \mathrm{~cm}^{-2}\right)$ of $\mathrm{CH}_{4}$, making it among the best catalysts toward $\mathrm{CH}_{4}$ formation ${ }^{7}$. For $\mathrm{C}_{2} \mathrm{H}_{4}$ and $\mathrm{C}_{2} \mathrm{H}_{5} \mathrm{OH}$ selectivity, the catalyst should have a slightly roughened surface so that the intermediates are stabilized and its $\mathrm{CO}_{2}$ reduction current density is maximized at regions from $-0.9 \mathrm{~V}$ to $-1.1 \mathrm{~V}$. To obtain a high faradaic efficiency of $\mathrm{CO}$ or $\mathrm{HCOO}^{-}$, the catalysts should be thick and rough oxide-derived films with high RFs. We note here that though smooth surfaces such as $\mathrm{Cu}(110)$, polycrystalline $\mathrm{Cu}$, and $\mathrm{Cu}-10$ could catalyze the reduction of $\mathrm{CO}_{2}$ to $\mathrm{HCOO}^{-}$or $\mathrm{CO}$ at more negative potentials, their selectivities are not comparable with those exhibited by thick $\mathrm{Cu}$ oxide films at less negative potentials ${ }^{13,43}$.

In this work, we prepared four Cu-based films by electrodeposition, and showed that they exhibited different selectivities toward $\mathrm{CO}_{2}$ reduction at different potential ranges. We highlight how limiting currents and applied potentials affect the selectivity of $\mathrm{CO}_{2}$ reduction reactions. This helps to rationalize the selectivity of different $\mathrm{Cu}$ catalysts, not only in this work, but also from many other reports. A FE of $\sim 40 \%$ of $\mathrm{CH}_{4}$ observed on $\mathrm{CuO}-1$ film at $-1.15 \mathrm{~V}$ contradicts with a proposition that $\mathrm{Cu}^{+}$or subsurface oxygen-modified $\mathrm{Cu}$ is the preferred catalyst for $\mathrm{C}_{2} \mathrm{H}_{4}$ selectivity. This study strongly shows that optimization of $\mathrm{CO}_{2}$ reduction current densities at the appropriate potential windows is critical for forming the type of product needed, and thus provides us with insights into how highly selective $\mathrm{Cu}$ catalysts could be rationally designed.

\section{Methods}

Preparation of electrocatalysts. The substrates were mechanically polished $\mathrm{Cu}$ discs (99.99\%, Goodfellow) with an exposed geometric surface area of $0.865 \mathrm{~cm}^{2}$. Two aqueous deposition electrolytes, A and B were prepared, for the depositions of metallic and oxide films, respectively.

Electrolyte A was prepared by first dissolving tartaric acid (Alfa Aesar, 99\%) in deionized water (18.2 $\mathrm{M} \Omega \mathrm{cm}$, Barnstead Type 1). $\mathrm{CuSO}_{4} 5 \mathrm{H}_{2} \mathrm{O}$ (GCE, 99\%) was then added. The solution was then cooled and continuously stirred in an ice water bath while $\mathrm{NaOH}$ (Chemicob, 99\%) was slowly added. The final $\mathrm{pH}$ of the solution was 10.5 , with the concentrations of tartaric acid, $\mathrm{CuSO}_{4} 5 \mathrm{H}_{2} \mathrm{O}$ and $\mathrm{NaOH}$ at, respectively, $0.2,0.2$, and $0.8 \mathrm{M}$. The deposition of $\mathrm{Cu}-10$ was carried out in a twoelectrode setup with a Pt wire as the counter electrode. Chronopotentiometry at 8 $\mathrm{mA} \mathrm{cm}-2$ for $10 \mathrm{~min}$ was used for the deposition of $\mathrm{Cu}-10$.

Electrolyte B was prepared similarly as above except that it had $2.5 \mathrm{M} \mathrm{NaOH}$ resulting in a $\mathrm{pH} 13.2$ solution. The deposition of $\mathrm{CuO}-1$ was carried out in a threeelectrode setup with a Pt wire and a $\mathrm{Ag} / \mathrm{AgCl}$ (Saturated $\mathrm{KCl}$, Pine) as the counter and reference electrodes, respectively. Chronamperometry at $1.47 \mathrm{~V}$ vs. RHE for 1 min (Autolab PGSTAT30) was used for the deposition of CuO-1. The deposition of $\mathrm{CuO}-10$ and $\mathrm{CuO}-60$ were carried out in a two-electrode setup with a Pt wire as the counter electrode. $\mathrm{CuO}-10$ and $\mathrm{CuO}-60$ were deposited by applying $8 \mathrm{~mA} \mathrm{~cm}{ }^{-2}$ for $10 \mathrm{~min}$ and $60 \mathrm{~min}$, respectively[22].

Characterization of the electrocatalysts. The chemical compositions of the catalysts were characterized using SAED (SAED, TEM mode, JEOL 3010, $300 \mathrm{kV}$, $112 \mu \mathrm{A}$ ) and Raman spectroscopy (Modular System, Horiba Jobin Yvon). A He-Ne laser was used as the excitation source and the acquisition time was 10 seconds for each spectrum. A dry objective (Olympus MPlan N, 50×, numerical aperture $=$ 0.75 ) and a water immersion objective (Olympus LUMFL, $60 \times$, numerical aperture $=1.10$ ) were, respectively, employed for ex situ and operando Raman spectroscopy. The morphologies of the catalysts were characterized by SEM (JEOL JSM$6710 \mathrm{~F}, 5 \mathrm{kV}$ ). Their electrochemical-active surface areas were determined by their double layer capacitances in $\mathrm{N}_{2}$-saturated $0.1 \mathrm{M} \mathrm{KClO}_{4}$ (99.9\%, Sigma Aldrich). A three-electrode setup was used with a $\mathrm{Pt}$ wire counter and a $\mathrm{Ag} / \mathrm{AgCl}$ reference electrode (Saturated $\mathrm{KCl}$, Pine). Cyclic voltammetry were performed in a nonfaradaic region from $-0.05 \mathrm{~V}$ to $0.05 \mathrm{~V}$ vs. RHE. The scan rates were $50,100,150$, $200,250,300,350$, and $400 \mathrm{mV} \mathrm{s}^{-1}$.

Electrochemical reduction of $\mathrm{CO}_{2} \cdot \mathrm{CO}_{2}$ electroreduction was performed in a custom built three-electrode electrochemical cell ${ }^{45}$. The reference and counter electrodes were, respectively, a $\mathrm{Ag} / \mathrm{AgCl}$ (saturated $\mathrm{KCl}$, Pine) and a coiled Pt wire. The cathodic and anodic compartments were separated by an anion exchange membrane (Asahi Glass). Both compartments were filled with $\mathrm{CO}_{2}$-saturated $0.1 \mathrm{M}$ 
$\mathrm{KHCO}_{3}\left(99.7 \%\right.$, Merck). During $60 \mathrm{~min}$ chronoamperometry, $20 \mathrm{~cm}^{3} \mathrm{~min}^{-1}$ of $\mathrm{CO}_{2}$ was continuously flowed into the electrolyte. The gas outlet of cathodic compartment was connected to a gas chromatograph (GC, Agilent 7890A) for the online quantification of gas products. The liquid products were quantified by headspace gas chromatography (HS-GC, Agilent 7890B) and high performance liquid chromatography (HPLC, Agilent 1260) after electrolysis. The voltage drop was automatically compensated using the current-interrupt mode available in the potentiostat (Gamry 600). The voltage was converted to the RHE scale and the current density was normalized to the exposed geometric surface area. All the detected products were quantified in terms of their FE. The FE of product $X$ is defined as:

$$
\mathrm{FE}(\mathrm{X})=\frac{\text { Number of electrons used for producing } \mathrm{X}}{\text { Total number of electrons used for electrolysis }} \times 100 \%
$$

Each reported FE value was the average of three independent sets of measurements.

Numerical simulations of local $\mathbf{p H}$ and $\mathrm{CO}_{2}$ concentration. Numerical simulations were performed with MATLAB 8.5 to calculate the local $\mathrm{pH}$ and how the concentration of $\mathrm{CO}_{2}$ near the electrode changed as a function of current density ${ }^{32}$. The electrode was taken to be planar (1-D model). The corresponding bulk concentration of $\mathrm{CO}_{2}, \mathrm{HCO}_{3}{ }^{-}, \mathrm{CO}_{3}{ }^{2-}$, and $\mathrm{H}^{+}$, diffusion coefficients, and rate constants were taken from the work of Gupta et al., along with the boundary conditions $\mathrm{s}^{32}$. The diffusion layer thickness was assumed to be $36 \mu \mathrm{m}^{54}$. The normalized current density (against the electrochemical-active surface area) and the FE were used for calculations ${ }^{18}$. Only the effect of diffusion and surface reaction were considered in this model. Only the $\mathrm{Cu}-10$ surface was simulated as it has a small roughness factor of 1.4, and, thus, its surface is close to planar.

Data availability. The data that support the findings of this study are available from the corresponding authors.

Received: 20 September 2017 Accepted: 1 February 2018

Published online: 02 March 2018

\section{References}

1. Aresta, M., Dibenedetto, A. \& Angelini, A. Catalysis for the valorization of exhaust Carbon: from $\mathrm{CO}_{2}$ to chemicals, materials, and fuels. technological use of $\mathrm{CO}_{2}$. Chem. Rev. 114, 1709-1742 (2013).

2. Ren, D., Loo, N. W. X., Gong, L. \& Yeo, B. S. Continuous production of ethylene from carbon dioxide and water using intermittent sunlight. ACS Sustainable Chem. Eng. 5, 9191-9199 (2017).

3. Hori, Y., Wakebe, H., Tsukamoto, T. \& Koga, O. Electrocatalytic process of $\mathrm{CO}$ selectivity in electrochemical reduction of $\mathrm{CO}_{2}$ at metal electrodes in aqueous media. Electrochim. Acta 39, 1833-1839 (1994).

4. Kuhl, K. P., Cave, E. R., Abram, D. N. \& Jaramillo, T. F. New insights into the electrochemical reduction of carbon dioxide on metallic copper surfaces. Energy Environ. Sci. 5, 7050-7059 (2012).

5. $\mathrm{Li}, \mathrm{C} . \mathrm{W}$. \& Kanan, M. W. $\mathrm{CO}_{2}$ Reduction at low overpotential on $\mathrm{Cu}$ electrodes resulting from the reduction of thick $\mathrm{Cu}_{2} \mathrm{O}$ films. J. Am. Chem. Soc. 134, 7231-7234 (2012)

6. Ma, M., Djanashvili, K. \& Smith, W. A. Selective electrochemical reduction of $\mathrm{CO}_{2}$ to $\mathrm{CO}$ on $\mathrm{CuO}$-derived $\mathrm{Cu}$ nanowires. Phys. Chem. Chem. Phys. 17, 20861-20867 (2015).

7. Manthiram, K., Beberwyck, B. J. \& Alivisatos, A. P. Enhanced electrochemical methanation of carbon dioxide with a dispersible nanoscale copper catalyst. J. Am. Chem. Soc. 136, 13319-13325 (2014).

8. Kas, R. et al. Electrochemical $\mathrm{CO}_{2}$ Reduction on $\mathrm{Cu}_{2} \mathrm{O}$-derived copper nanoparticles: controlling the catalytic selectivity of hydrocarbons. Phys. Chem. Chem. Phys. 16, 12194-12201 (2014).

9. Ren, D. et al. Selective electrochemical reduction of carbon dioxide to ethylene and ethanol on copper(I) oxide catalysts. ACS Catal. 5, 2814-2821 (2015).

10. Mistry, H. et al. Highly selective plasma-activated copper catalysts for carbon dioxide reduction to ethylene. Nat. Commun. 7, 12123 (2016).

11. Ren, D., Ang, B. S.-H. \& Yeo, B. S. Tuning the selectivity of carbon dioxide electroreduction toward ethanol on Oxide-Derived $\mathrm{Cu}_{\mathrm{x}} \mathrm{Zn}$ catalysts. ACS Catal. 6, 8239-8247 (2016).

12. Peterson, A. A., Abild-Pedersen, F., Studt, F., Rossmeisl, J. \& Nørskov, J. K. How copper catalyzes the electroreduction of carbon dioxide into hydrocarbon fuels. Energy Environ. Sci. 3, 1311-1315 (2010).

13. Hori, Y., Murata, A. \& Takahashi, R. Formation of hydrocarbons in the electrochemical reduction of carbon dioxide at a copper electrode in aqueous solution. J. Chem. Soc., Faraday Trans. 1 85, 2309-2326 (1989).

14. Hori, Y., Takahashi, I., Koga, O. \& Hoshi, N. Electrochemical reduction of carbon dioxide at various series of copper single crystal electrodes. J. Mol. Catal. A: Chem. 199, 39-47 (2003).
15. Kim, D. et al. Insights into an autonomously formed oxygen-evacuated $\mathrm{Cu}_{2} \mathrm{O}$ electrode for the selective production of $\mathrm{C}_{2} \mathrm{H}_{4}$ from $\mathrm{CO}_{2}$. Phys. Chem. Chem. Phys. 17, 824-830 (2015).

16. Ma, S. et al. One-step electrosynthesis of ethylene and ethanol from $\mathrm{CO}_{2}$ in an alkaline electrolyzer. J. Power Sources 301, 219-228 (2016).

17. Reske, R., Mistry, H., Behafarid, F., Roldan Cuenya, B. \& Strasser, P. Particle size effects in the catalytic electroreduction of $\mathrm{CO}_{2}$ on $\mathrm{Cu}$ nanoparticles. J. Am. Chem. Soc. 136, 6978-6986 (2014).

18. Handoko, A. D. et al. Mechanistic insights into the selective electroreduction of carbon dioxide to ethylene on $\mathrm{Cu}_{2} \mathrm{O}$-Derived copper catalysts. J. Phys. Chem. C. 120, 20058-20067 (2016).

19. Verdaguer-Casadevall, A. et al. Probing the active surface sites for CO reduction on Oxide-Derived copper electrocatalysts. J. Am. Chem. Soc. 137, 9808-9811 (2015).

20. Li, C. W., Ciston, J. \& Kanan, M. W. Electroreduction of carbon monoxide to liquid fuel on oxide-derived nanocrystalline copper. Nature 508, 504-507 (2014).

21. Eilert, A. et al. Subsurface oxygen in Oxide-Derived copper electrocatalysts for carbon dioxide reduction. J. Phy. Chem. Lett. 8, 285-290 (2017).

22. Deng, Y., Handoko, A. D., Du, Y., Xi, S. \& Yeo, B. S. In situ raman spectroscopy of copper and copper oxide surfaces during electrochemical oxygen evolution reaction: identification of $\mathrm{Cu}^{\text {III }}$ oxides as catalytically active species. ACS Catal. 6, 2473-2481 (2016).

23. Chen, X. K., Irwin, J. C. \& Franck, J. P. Evidence for a strong spin-phonon interaction in cupric oxide. Phys. Rev. B 52, R13130 (1995).

24. Beverskog, B. \& Puigdomenech, I. Revised Pourbaix diagrams for copper at 25 to 300 C. J. Electrochem. Soc. 144, 3476-3483 (1997).

25. Akemann, W. \& Otto, A. Vibrational modes of $\mathrm{CO}$ adsorbed on disordered copper films. J. Raman Spectrosc. 22, 797-803 (1991).

26. Oda, I., Ogasawara, H. \& Ito, M. Carbon monoxide adsorption on copper and silver electrodes during carbon dioxide electroreduction studied by infrared reflection absorption spectroscopy and surface-enhanced Raman spectroscopy. Langmuir 12, 1094-1097 (1996)

27. Smith, B., Irish, D., Kedzierzawski, P. \& Augustynski, J. A surface enhanced raman scattering study of the intermediate and poisoning species formed during the electrochemical reduction of $\mathrm{CO}_{2}$ on copper. J. Electrochem. Soc. 144, 4288-4296 (1997).

28. Hori, Y., Murata, A. \& Yoshinami, Y. Adsorption of CO, intermediately formed in electrochemical reduction of $\mathrm{CO}_{2}$, at a copper electrode. J. Chem. Soc., Faraday Trans. 87, 125-128 (1991).

29. Chen, C. S., Wan, J. H. \& Yeo, B. S. Electrochemical reduction of carbon dioxide to ethane using nanostructured $\mathrm{Cu}_{2} \mathrm{O}$-Derived copper catalyst and Palladium (II) chloride. J. Phys. Chem. C. 119, 26875-26882 (2015).

30. Singh, M. R., Kwon, Y., Lum, Y., Ager, J. W. \& Bell, A. T. Hydrolysis of electrolyte cations enhances the electrochemical reduction of $\mathrm{CO}_{2}$ over $\mathrm{Ag}$ and Cu. J. Am. Chem. Soc. 138, 13006-13012 (2016).

31. Lum, Y., Yue, B., Lobaccaro, P., Bell, A. T. \& Ager, J. W. Optimizing C-C coupling on Oxide-Derived copper catalysts for electrochemical $\mathrm{CO}_{2}$ reduction. J. Phys. Chem. C. 121, 14191-14203 (2017).

32. Gupta, N., Gattrell, M. \& MacDougall, B. Calculation for the cathode surface concentrations in the electrochemical reduction of $\mathrm{CO}_{2}$ in $\mathrm{KHCO}_{3}$ solutions. J. Appl. Electrochem. 36, 161-172 (2005).

33. Durand, W. J., Peterson, A. A., Studt, F., Abild-Pedersen, F. \& Nørskov, J. K. Structure effects on the energetics of the electrochemical reduction of $\mathrm{CO}_{2}$ by copper surfaces. Surf. Sci. 605, 1354-1359 (2011).

34. Schouten, K., Kwon, Y., Van der Ham, C., Qin, Z. \& Koper, M. A new mechanism for the selectivity to $C_{1}$ and $C_{2}$ species in the electrochemical reduction of carbon dioxide on copper electrodes. Chem. Sci. 2, 1902-1909 (2011).

35. Calle-Vallejo, F. \& Koper, M. T. M. Theoretical considerations on the electroreduction of $\mathrm{CO}$ to $\mathrm{C}_{2}$ species on $\mathrm{Cu}(100)$ electrodes. Angew. Chem. Int. Ed. 52, 7282-7285 (2013).

36. Feaster, J. T. et al. Understanding selectivity for the electrochemical reduction of carbon dioxide to formic acid and carbon monoxide on metal electrodes. ACS Catal. 7, 4822-4827 (2017).

37. Seh, Z. W. et al. Combining theory and experiment in electrocatalysis: insights into materials design. Science 355, eaad4998 (2017).

38. Kortlever, R., Shen, J., Schouten, K. J. P., Calle-Vallejo, F. \& Koper, M. T. M. Catalysts and reaction pathways for the electrochemical reduction of carbon dioxide. J. Phy. Chem. Lett. 6, 4073-4082 (2015).

39. Tang, W. et al. The importance of surface morphology in controlling the selectivity of polycrystalline copper for $\mathrm{CO}_{2}$ electroreduction. Phys. Chem. Chem. Phys. 14, 76-81 (2012).

40. Chen, C. S. et al. Stable and selective electrochemical reduction of carbon dioxide to ethylene on copper mesocrystals. Catal. Sci. Technol. 5, 161-168 (2015).

41. Roberts, F. S., Kuhl, K. P. \& Nilsson, A. High selectivity for ethylene from carbon dioxide reduction over copper nanocube electrocatalysts. Angew. Chem. Int. Ed. 54, 5179-5182 (2015). 
42. Takahashi, I., Koga, O., Hoshi, N. \& Hori, Y. Electrochemical reduction of $\mathrm{CO}_{2}$ at copper single crystal $\mathrm{Cu}(\mathrm{S})-[\mathrm{n}(111) \times(111)]$ and $\mathrm{Cu}(\mathrm{S})-[\mathrm{n}(110) \times(100)]$ electrodes. J. Electroanal. Chem. 533, 135-143 (2002).

43. Huang, Y., Handoko, A. D., Hirunsit, P. \& Yeo, B. S. Electrochemical reduction of $\mathrm{CO}_{2}$ using copper single-crystal surfaces: effects of $\mathrm{CO}^{*}$ coverage on the selective formation of ethylene. ACS Catal. 7, 1749-1756 (2017).

44. Hahn, C. et al. Engineering $\mathrm{Cu}$ surfaces for the electrocatalytic conversion of $\mathrm{CO}_{2}$ : controlling selectivity toward oxygenates and hydrocarbons. Proc. Natl. Acad. Sci. USA 114, 5918-5923 (2017).

45. Ren, D., Wong, N. T., Handoko, A. D., Huang, Y. \& Yeo, B. S. Mechanistic insights into the enhanced activity and stability of agglomerated $\mathrm{Cu}$ nanocrystals for the electrochemical reduction of carbon dioxide to n-propanol. J. Phy. Chem. Lett. 6, 20-24 (2016).

46. Kwon, Y., Lum, Y., Clark, E. L., Ager, J. W. \& Bell, A. T. $\mathrm{CO}_{2}$ Electroreduction with enhanced ethylene and ethanol selectivity by nanostructuring polycrystalline copper. ChemElectroChem. 3, 1012-1019 (2016).

47. Loiudice, A. et al. Tailoring copper nanocrystals towards $C_{2}$ products in electrochemical $\mathrm{CO}_{2}$ reduction. Angew. Chem. Int. Ed. 55, 5789-5792 (2016).

48. Gupta, K., Bersani, M. \& Darr, J. A. Highly efficient electro-reduction of $\mathrm{CO}_{2}$ to formic acid by nano-copper. J. Mat. Chem. A 4, 13786-13794 (2016).

49. Ma, S. et al. Electroreduction of carbon dioxide to hydrocarbons using bimetallic $\mathrm{Cu}-\mathrm{Pd}$ catalysts with different mixing patterns. J. Am. Chem. Soc. 139, 47-50 (2017).

50. Burdyny, T. et al. Nanomorphology-enhanced gas-evolution intensifies $\mathrm{CO}_{2}$ reduction electrochemistry. ACS Sustainable Chem. Eng. 5, 4031-4040 (2017).

51. Lee, S., Kim, D. \& Lee, J. Electrocatalytic production of C3-C4 Compounds by conversion of $\mathrm{CO}_{2}$ on a chloride-induced bi-phasic $\mathrm{Cu}_{2} \mathrm{O}-\mathrm{Cu}$ catalyst. Angew. Chem. Int. Ed. 54, 14701-14705 (2015).

52. Schouten, K. J. P., Pérez Gallent, E. \& Koper, M. T. M. The influence of $\mathrm{pH}$ on the reduction of $\mathrm{CO}$ and to hydrocarbons on copper electrodes. J. Electroanal. Chem. 716, 53-57 (2014).

53. Schouten, K. J. P., Qin, Z., Gallent, E. P. \& Koper, M. T. M. Two pathways for the formation of ethylene in $\mathrm{CO}$ reduction on Single-crystal copper electrodes. J. Am. Chem. Soc. 134, 9864-9867 (2012).

54. Bumroongsakulsawat, P. \& Kelsall, G. H. Effect of solution $\mathrm{pH}$ on CO: formate formation rates during electrochemical reduction of aqueous $\mathrm{CO}_{2}$ at $\mathrm{Sn}$ cathodes. Electrochim. Acta 141, 216-225 (2014).

\section{Acknowledgements}

This work is supported by a research grant, R-143-000-683-112, from the Ministry of Education, Singapore. D.R. acknowledges a Ph.D. research scholarship from the Ministry of Education, Singapore. We thank Cheng Wai Ong (NUS) for performing the numerical simulations.

\section{Author contributions}

D.R., and B.S.Y. conceived the idea and designed the experiments. D.R., and J.F. ran the electrochemistry measurements. D.R. characterized the samples. B.S.Y. supervised the project. All the authors analyzed the data and contributed to the final manuscript.

\section{Additional information}

Supplementary Information accompanies this paper at https://doi.org/10.1038/s41467018-03286-w.

Competing interests: The authors declare no competing financial interests.

Reprints and permission information is available online at http://npg.nature.com/ reprintsandpermissions/

Publisher's note: Springer Nature remains neutral with regard to jurisdictional claims in published maps and institutional affiliations.

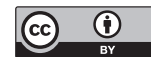

Open Access This article is licensed under a Creative Commons Attribution 4.0 International License, which permits use, sharing, adaptation, distribution and reproduction in any medium or format, as long as you give appropriate credit to the original author(s) and the source, provide a link to the Creative Commons license, and indicate if changes were made. The images or other third party material in this article are included in the article's Creative Commons license, unless indicated otherwise in a credit line to the material. If material is not included in the article's Creative Commons license and your intended use is not permitted by statutory regulation or exceeds the permitted use, you will need to obtain permission directly from the copyright holder. To view a copy of this license, visit http://creativecommons.org/ licenses/by/4.0/.

(C) The Author(s) 2018 